\title{
PERUBAHAN PENGUNAAN LAHAN DAN PENGARUHNYA TERHADAP PERUBAHAN IKLIM KOTA MALANG
}

\author{
1) Akhmad Faruq Hamdani; ${ }^{2)}$ Nelya Eka Susanti \\ 1) 2) Universitas Kanjuruhan Malang \\ Email: ${ }^{1)}$ a.faruqhamdani@ unikama.ac.id; ${ }^{2)}$ nelyaeka@unikama.ac.id
}

\begin{abstract}
Abstrak
Perkembangan kota dengan semakin meningkatnya jumlah penduduk akan meningkatkan kebutuhan terhadap lahan. Perubahan lahan terbuka menjadi lahan tertutup akan meningkatkan suhu udara di wilayah perkotaan. Tujuan dari penelitian ini untuk menganalisis perubahan penggunaan lahan dan pengaruhnya terhadap perubahan suhu udara di Kota Malang pada 25 tahun terakhir. Hal ini berkaitan dengan banyaknya perubahan lahan terbuka menjadi lahan tertutup di Kota Malang. Tahapan penelitian yang dilakukan yakni; 1) mengumpulkan data yang dibutuhkan dalam penelitian; 2) Melakukan analisis kepadatan penduduk Kota Malang, 3) Melakukan analisis suhu udara di Kota Malang yang kemudian dihitung rata-rata tahunan dan rata-rata bulanannya; 4) Melakukan analisis regresi linier sederhana untuk menghitung pengaruh antar variabel; 5) Melakukan survey lapangan untuk mengetahui kecocokan antara hasil analisis yang telah didapatkan dengan kondisi di lapangan. Berdasarkan uraian hasil penelitian di atas diperoleh hasil bahwa kepadatan penduduk Kota Malang pada tahun 1991 adalah $6369,65 \mathrm{jiwa} / \mathrm{km}^{2}$ dan pada tahun 2016 adalah 7734,26 jiwa/ $\mathrm{km}^{2}$. Terdapat kenaikan $\pm 1000 \mathrm{jiwa} / \mathrm{km}^{2}$ dalam 25 tahun. Berdasarkan hasil analisis suhu udara Kota Malang selama 25 tahun diperoleh telah mengalami rata-rata kenaikan suhu udara $1,59^{\circ} \mathrm{C}$, dengan suhu udara bulanan tertinggi terjadi pada bulan April 2016 dan suhu udara terendah terjadi pada bulan Agustus 1995 dengan suhu udara 21,581 ${ }^{\circ} \mathrm{C}$. Kepadatan penduduk berpengaruh terhadap penggunaan tata guna lahan dan berpengaruh terhadap peningkatan suhu udara di Kota Malang dari tahun 1991 - 2016. Kepadatan penduduk di Kota Malang memiliki pengaruh sebesar 49,6\% terhadap perubahan suhu, sedangkan $50,4 \%$ peningkatan suhu dipengaruhi oleh variabel lain.
\end{abstract}

Kata Kunci: Penggunaan Lahan, perubahan, iklim, Kota Malang.

\section{PENDAHULUAN}

Perubahan tata guna lahan di wilayah kota terus meningkat dari waktu ke waktu. Penggunaan lahan pada saat sekarang merupakan pertanda adanya dinamika dari eksploitasi sumber daya manusia, baik secara perorangan ataupun masyarakat (Ritohardoyo, 2013). Perubahan penggunaan lahan yang terjadi sejalan dengan semakin meningkatnya pertambahan jumlah penduduk yang secara langsung berdampak pada kebutuhan terhadap lahan yang semakin meningkat (Kusrini, Suharyadi, dan Hardoyo, 2011).
Perkembangan fisik Kota Malang dalam kurun waktu 4 tahun dari tahun 19972001 mengakibatkan terjadi penyusutan lahan pertanian sebesar $1,08 \%$ per tahun dari total luas wilayah (Bappedalda Kota Malang dalam Utaya, 2008). Akibat perubahan penggunaan lahan kota Malang menyebabkan proporsi lahan terbuka menjadi $5.729,46$ ha, yang mencakup lahan sawah, tegalan, tanah kosong, lapangan olahraga/taman, kuburan, dan tempat rekreasi (Utaya, 2008).

Pertambahan jumlah penduduk kota berarti juga peningkatan kebutuhan lahan. Karena lahan tidak dapat 
bertambah, maka yang terjadi adalah perubahan penggunaan lahan yang cenderung menurunkan proporsi lahanlahan yang sebelumnya merupakan penggunaan lahan pertanian menjadi lahan non pertanian.

Perubahan penggunaan lahan selain menambah proporsi luas lahan terbangun, juga mengubah tutupan lahan/vegetasi pada lahan terbuka yaitu dari lahan sawah/ tegalan menjadi rumput/pekarangan (Utaya, 2008). Perubahan penggunaan lahan perkotaan akan mempercepat proses perubahan iklim. Iklim merubakan kondisi ratarata suhu udara, curah hujan, tekanan udara, arah angin, kelembaban udara dan parameter iklim lainnya dalam jangka waktu yang panjang (Tjasyono, 2004). Apabila terjadi perubahan dari kondisi rata-rata parameter iklim, maka hal tersebut dikatakan sebagai perubahan iklim (Setiawan, 2012).

Perubahan iklim ini diakibatkan oleh semakin meningkatnya konsentrasi Gas Rumah Kaca (GRK) seperti CO , CH, NO, HFC, PFC, dan SF di atmosfer. Dampak perubahan iklim adalah perubahan pola hujan, kenaikan muka air laut, dan kenaikan suhu udara (Setiawan, 2012). . Proses perubahan iklim yang salah satunya berdampak terhadap peningkatan suhu udara akan memberikan dampak negatif terhadap kehidupan masyarakat kota. Peningkatan suhu udara akan menyebabkan dampak terhadap tingkat kesehatan, kualitas ruang, dan tingkat kenyamanan bagi masyarakatnya.

Wilayah perkotaan merupakan pusat berbagai aktivitas manusia dengan segala kreativitas, dan budaya yang menunjukkan kemajuan sosial dan ekonominya. Interaksi antara manusia terhadap kondisi lahan akan berakibat terhadap peningkatan suhu udara. Wilayah perkotaan selalu menderita akibat dari adanya kenaikan suhu udara, atau lebih dikenal dengan urban heat island effect (Moonen, et.al, 2012). Suhu udara terjebak dalam bangunan hasil bentukan manusia. Semakin padat suatu wilayah maka potensi meningkatnya suhu udara akan semakin besar, dan semakin renggang suatu wilayah maka potensi meningkatnya suhu udara akan semakin kecil.

Perubahan lahan terbuka menjadi lahan tertutup akan meningkatkan suhu udara di wilayah perkotaan. Oleh karena itu tujuan dari penelitian ini untuk menganalisis perubahan penggunaan lahan dan pengaruhnya terhadap perubahan suhu udara di Kota Malang pada 25 tahun terakhir. Hal ini berkaitan dengan banyaknya perubahan lahan terbuka menjadi lahan tertutup di Kota Malang.

\section{METODE PENELITIAN}

Jenis penelitian yang dilakukan adalah jenis penelitian kuantitatif. Penelitian dilakukan di Kota Malang dengan menganalisis variasi kepadatan penduduk, perubahan suhu udara, dan perubahan penggunaan lahan.

Tahapan penelitian yang dilakukan yakni:

1. Mengumpulkan data yang dibutuhkan dalam penelitian, yang mencakup data suhu udara Kota Malang tahun 1991-2016 dari BMKG Karangploso melalui (http://dataonline.bmkg.go.id/home), data jumlah penduduk Kota Malang tahun 1991-2016 dari Badan Pusat Statistik Kota Malang, citra google earth Kota Malang tahum 1991-2016 
yang didapatkan dari google earth pro 7.1.

2. Melakukan analisis kepadatan penduduk Kota Malang dengan rumus:

$$
K P=\frac{\text { Jumlah Penduduk }(\text { jiwa })}{\text { Luas Wilayah }\left(\mathrm{km}^{2}\right)}
$$

(Muta'ali, 2012).

Jumlah Penduduk yang digunakan adalah jumlah penduduk Kota Malang Tahun 1991-2016. Jumlah penduduk Kota Malang tahun 19912010 dihitung dengan metode proyeksi kilas balik dan tahun 20112016 dengan metode geometrik, yakni:

a. Menghitung rata-rata laju pertumbuhan penduduk tahun dengan metode geometrik dari tahun 1990-2000 dan 2000-2010 dengan rumus:

$$
r=\left(\frac{P t}{P o}\right)^{\frac{1}{t}}-1
$$

(BPS, 2013)

Ket:

$\mathrm{r}$ = laju pertumbuhan penduduk

$\mathrm{Pt}=$ jumlah penduduk tahun $\mathrm{t}$ (2000/2010)

$\mathrm{Po}=$ jumlah penduduk tahun dasar (1990/2000)

$\mathrm{t}=$ periode waktu tahun dasar dan tahun $\mathrm{t}$

b. Mengistimasi jumlah penduduk berdasarkan laju pertumbuhan penduduk yang sudah dihitung, dengan rumus:

(BPS, 2013)

$$
P t=P o(1+r)^{t}
$$

Ket:

$\mathrm{Pt}=$ jumlah penduduk tahun $\mathrm{t}$

Po $=$ jumlah penduduk tahun dasar

$r \quad=$ laju pertumbuhan penduduk.

3. Melakukan analisis suhu udara di Kota Malang yang kemudian dihitung rata-rata tahunan dan ratarata bulanannya.

4. Melakukan analisis regresi linier sederhana untuk menghitung pengaruh antar variabel.

5. Melakukan survey lapangan untuk mengetahui kecocokan antara hasil analisis yang telah didapatkan dengan kondisi di lapangan.

\section{HASIL DAN PEMBAHASAN}

\section{Kepadatan Permukiman Kota Malang}

Hasil analisis kepadatan permukiman merupakan hasil penghitungan kepadatan penduduk Kota Malang mulai tahun 1990-2016. Jumlah penduduk tahun 1990-2010 dihitung berdasarkan metode proyeksi kilas balik (backcasting) berdasarkan hasil SP90, SP2000, dan SP2010. Sedangkan untuk jumlah penduduk tahun 2011-2016 dihitung berdasarkan SP2010 dengan mempertimbangkan laju pertumbuhan penduduk Kota Malang berdasarkan proyeksi penduduk Indonesia 2010 2035 sebesar 0,62\% (BPS, 2013).

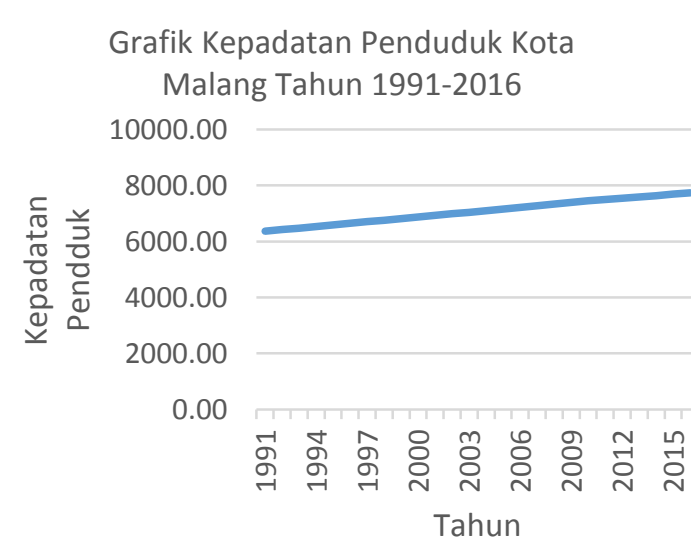
Gambar 1. Grafik Kepadatan Penduduk Kota Malang Tahun 1971- 2016 
Dari grafik kepadatan penduduk Kota Malang di atas dapat diketahui bahwa kepadatan penduduk di Kota Malang terus meningkat dari tahun 1991 hingga tahun 2016. Berikut rincian data jumlah data kepadatan penduduk di Kota Malang tahun 1991-2016.

\section{Tabel 1. Jumlah dan Kepadatan Penduduk Kota Malang Tahun} 1991-2016

\begin{tabular}{lrrr}
\hline No & Tahun & $\begin{array}{c}\text { Jumlah } \\
\text { Penduduk }\end{array}$ & $\begin{array}{c}\text { Kepadatan } \\
\text { Penduduk } \\
\text { (jiwa/km2) }\end{array}$ \\
\hline 1 & 1991 & 701043 & 6369.65 \\
2 & 1992 & 707049 & 6424.21 \\
3 & 1993 & 713106 & 6479.25 \\
4 & 1994 & 719215 & 6534.75 \\
5 & 1995 & 725376 & 6590.73 \\
6 & 1996 & 731590 & 6647.19 \\
7 & 1997 & 737857 & 6704.13 \\
8 & 1998 & 744177 & 6761.56 \\
9 & 1999 & 750552 & 6819.48 \\
0 & 2000 & 756982 & 6877.90 \\
11 & 2001 & 763082 & 6933.33 \\
12 & 2002 & 769231 & 6989.20 \\
13 & 2003 & 775430 & 7045.52 \\
4 & 2004 & 781679 & 7102.30 \\
15 & 2005 & 787978 & 7159.53 \\
16 & 2006 & 794328 & 7217.22 \\
17 & 2007 & 800729 & 7275.38 \\
18 & 2008 & 807181 & 7334.01 \\
19 & 2009 & 813686 & 7393.11 \\
20 & 2010 & 820243 & 7452.69 \\
21 & 2011 & 825329 & 7498.90 \\
22 & 2012 & 830446 & 7545.39 \\
23 & 2013 & 835594 & 7592.17 \\
24 & 2014 & 840775 & 7639.24 \\
25 & 2015 & 845988 & 7686.61 \\
26 & 2016 & 851233 & 7734.26 \\
\hline Sumber: & &
\end{tabular}

Sumber: Hasil Analisis

Berdasarkan hasil analisis data pada tabel 1 di atas, menunjukkan kepadatan penduduk Kota Malang pada tahun 1991 adalah 6369,65 jiwa/ $/ \mathrm{km}^{2}$ dan pada tahun 2016 adalah 7734,26 jiwa/ km². Terdapat kenaikan $\pm 1000 \mathrm{jiwa} / \mathrm{km}^{2}$ dalam 25 tahun. Berdasarkan hasil analisis laju pertumbuhan penduduk geometrik Kota Malang pada tahun 1991-2016 diperoleh laju pertumbuhan penduduk sebesar $0,76 \%$.

Penurunan laju pertumbuhan penduduk akan menyebabkan penurunan tingkat kepadatan penduduk perkotaan, sebaliknya peningkatan laju pertumbuhan penduduk akan meningkatkan tingkat kepadatan penduduk perkotaan. Semakin meningkatnya jumlah penduduk maka akan semakin meningkatkan tekanan penduduk terhadap ketersediaan lahan, karena jumlah penduduk terus meningkat tetapi luas lahan tetap (Muta'ali, 2012).

Menurut Todaro (2000) cepatnya pertumbuhan penduduk telah menimbulkan masalah krisis kesehatan di daerah perkotaan. Selain itu lonjakan penduduk juga mengakibatkan degradasi lingkungan atau pengikisan sumber daya alam. Pertambahan jumlah pendudukan menyebabkan menyempitnya lahan terbuka. Pertambahan jumlah penduduk juga menyebabkan degradasi lingkungan, salah satunya adalah perubahan iklim di Kota Malang.

\section{Variasi Perubahan Suhu Udara Kota Malang}

Kota Malang dengan heterogenitas kegiatan yang ada didalamnya berdampak terhadap perubahan suhu udara. Semakin padat suatu wilayah maka potensi meningkatnya suhu udara akan semakin tinggi. 
Tabel 2. Rata-Rata Perubahan Suhu Udara Tahunan Kota Malang Tahun 1991-2016

\begin{tabular}{cr}
\hline Tahun & Suhu udara $\left(^{0} \mathbf{C}\right)$ \\
\hline 1991 & 23.512 \\
1992 & 23.599 \\
1993 & 23.773 \\
1994 & 23.351 \\
1995 & 23.679 \\
1996 & 23.685 \\
1997 & 23.790 \\
1998 & 24.583 \\
1999 & 23.798 \\
2000 & 23.952 \\
2001 & 23.988 \\
2002 & 24.133 \\
2003 & 24.075 \\
2004 & 24.220 \\
2005 & 23.964 \\
2006 & 23.922 \\
2007 & 23.819 \\
2008 & 24.196 \\
2009 & 24.196 \\
2010 & 24.536 \\
2011 & 23.901 \\
2012 & 23.978 \\
2013 & 24.145 \\
2014 & 24.326 \\
2015 & 24.455 \\
2016 & 25.100 \\
\hline
\end{tabular}

Sumber: Hasil Analisis

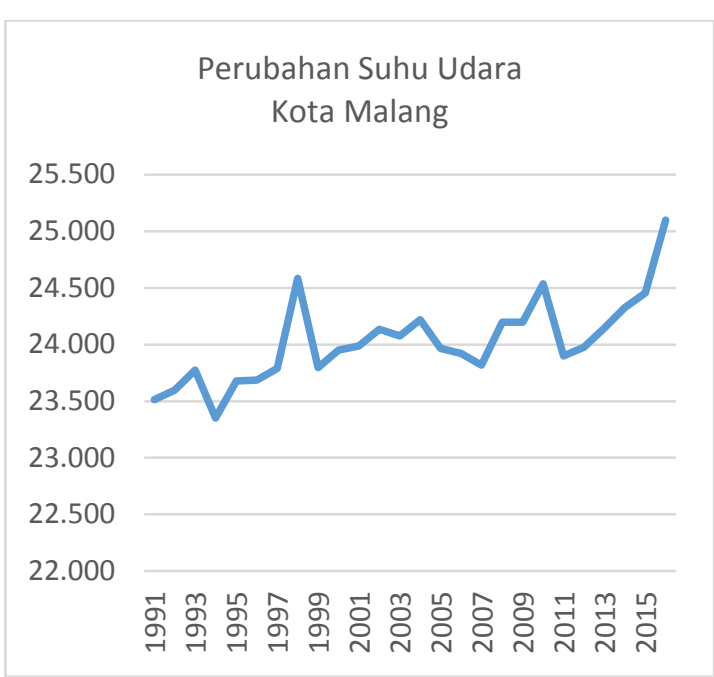

\section{Gambar 2. Grafik Perubahan Rata- Rata Suhu Udara Kota Malang Tahun 1991-2016}

Berdasarkan hasil analisis menunjukkan suhu udara cenderung mengalami kenaikan mulai tahun 1991-2016. Ratarata suhu udara tahunan tertinggi terjadi pada tahun 2016 dengan suhu udara $25,1^{0} \mathrm{C}$, sedangkan suhu udara tertinggi terjadi pada tahun 1994 dengan suhu udara $23,351^{\circ} \mathrm{C}$.

Sejak tahun 1991 - 2016 suhu udara Kota Malang telah mengalami rata-rata kenaikan suhu udara $1,59{ }^{0} \mathrm{C}$. Hal ini sesuai dengan Assement Report $V$ yang disusun oleh Intergovermental Panel on Climate Change (IPCC) menyebutkan bahwa diakhir abad 21 peningkatan suhu permukaan global diproyeksikan melebihi $1,5-2^{0} \mathrm{C}$ (IPCC, 2014).

Peningkatan suhu di Kota Malang salah satunya disebabkan oleh meningkatnya jumlah penduduk di Kota Malang. Peningkatan jumlah penduduk akan berdampak pada kurangnya ruang terbuka hijau di perkotaan dan peningkatan jumlah kendaraan bermotor. Dengan semakin berkurangnya ruang terbuka hijau maka vegetasi yang berfungsi untuk menyerap panas matahari semakin sedikit. 
Vegetasi yang berfungsi untuk menurunkan suhu udara pada siang hari dan meningkatkan suhu udara pada malam hari menjadi hilang fungsinya. Hal tersebut memberikan dampak terhadap peningkatan suhu di Kota Malang. Berikut grafik peningkatan suhu di Kota Malang tiap bulan pada tahun 1991-2016.

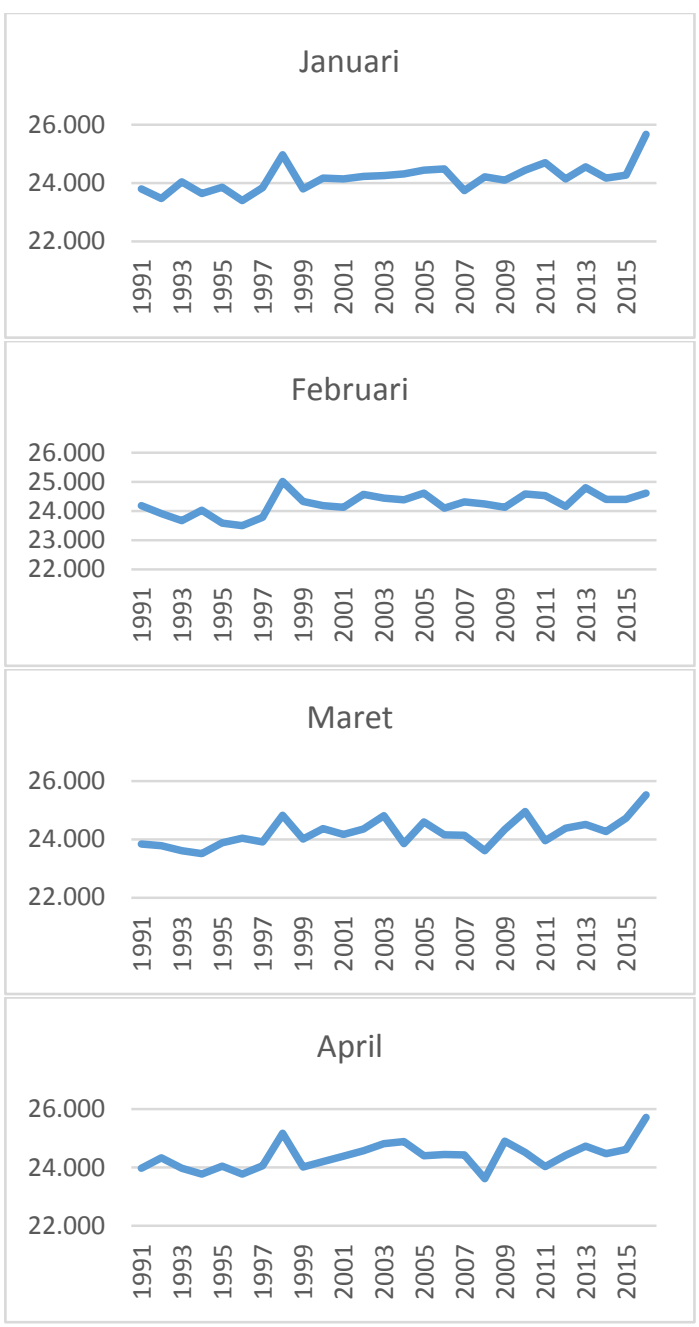

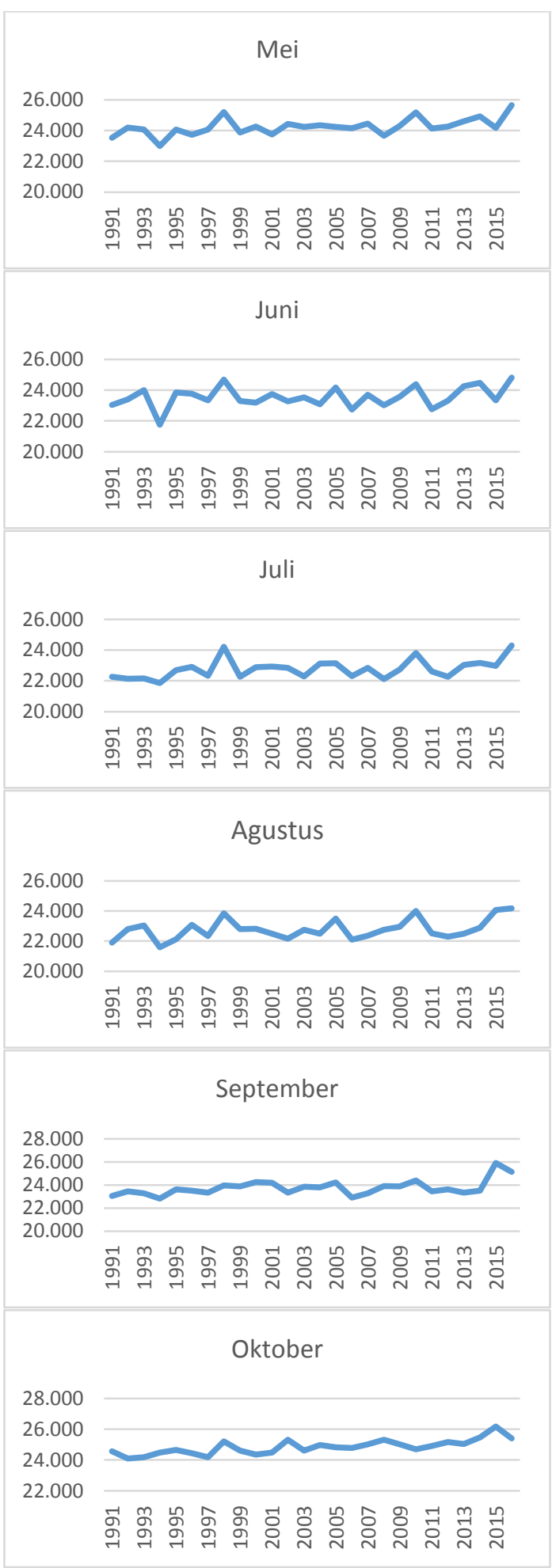




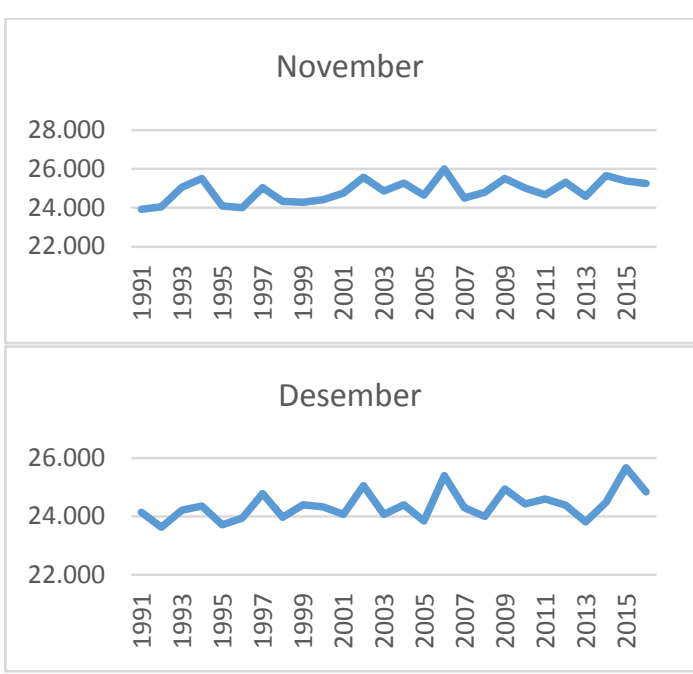

Gambar 3. Grafik Perubahan Suhu Udara Bulanan Kota Malang Tahun 1991-2016

Berdasarkan hasil analisis menunjukkan suhu udara bulanan tertinggi terjadi pada bulan April 2016 dengan suhu udara mencapai $25,724{ }^{0} \mathrm{C}$, sedangkan suhu udara terendah terjadi pada bulan Agustus 1995 dengan suhu udara $21,581{ }^{\circ} \mathrm{C}$. Rata-rata bulanan selama 25 tahun terakhir di Kota Malang secara berturut-turut pada bulan Januari $24,188^{\circ} \mathrm{C}$, bulan Februari $24,254^{\circ} \mathrm{C}$, bulan Maret $24,240^{\circ} \mathrm{C}$, bulan April $24,394^{\circ} \mathrm{C}$, bulan Mei, $24,256^{\circ} \mathrm{C}$, bulan Juni $23,562^{\circ} \mathrm{C}$, bulan Juli $22,780^{\circ} \mathrm{C}$, bulan Agutus $22,776^{\circ} \mathrm{C}$, bulan September $23,769^{\circ} \mathrm{C}$, bulan Oktober $24,849^{\circ} \mathrm{C}$, bulan November $24,870^{\circ} \mathrm{C}$, dan bulan Desember $24,378^{\circ} \mathrm{C}$. Ratarata suhu udara bulanan tertinggi terjadi pada bulan Oktober dan suhu udara bulanan terendah terjadi pada bulan Agustus.

\section{Perubahan Tata Guna Lahan terhadap Perubahan Iklim}

Perubahan iklim secara alamiah akan terus terjadi, namun faktor manusia saat ini akan mempercepat terjadinya perubahan iklim. Perubahan iklim yang salah satunya ditunjukkan melalui kenaikan suhu udara saat ini dan masa depan akan berdampak terhadap kehidupan manusia. Karena manusia mempengaruhi kondisi lingkungan dan kondisi lingkungan akan mempengaruhi kehidupan manusia.

Perubahan tata guna lahan sebagai salah satu dinamika perkotaan berdampak terhadap kenaikan suhu udara di Kota Malang. Perubahan tata guna lahan sebagai akibat kenaikan jumlah penduduk Kota Malang dari tahun ke tahun berpengaruh terhadap perubahan tata guna lahannya. Pembangunan wilayah perkotaan yang terus meningkat dari tahun ke tahun yang menyebabkan bekurangnya luasan ruang terbuka hijau dan meningkatnya luasan lahan tertutup.
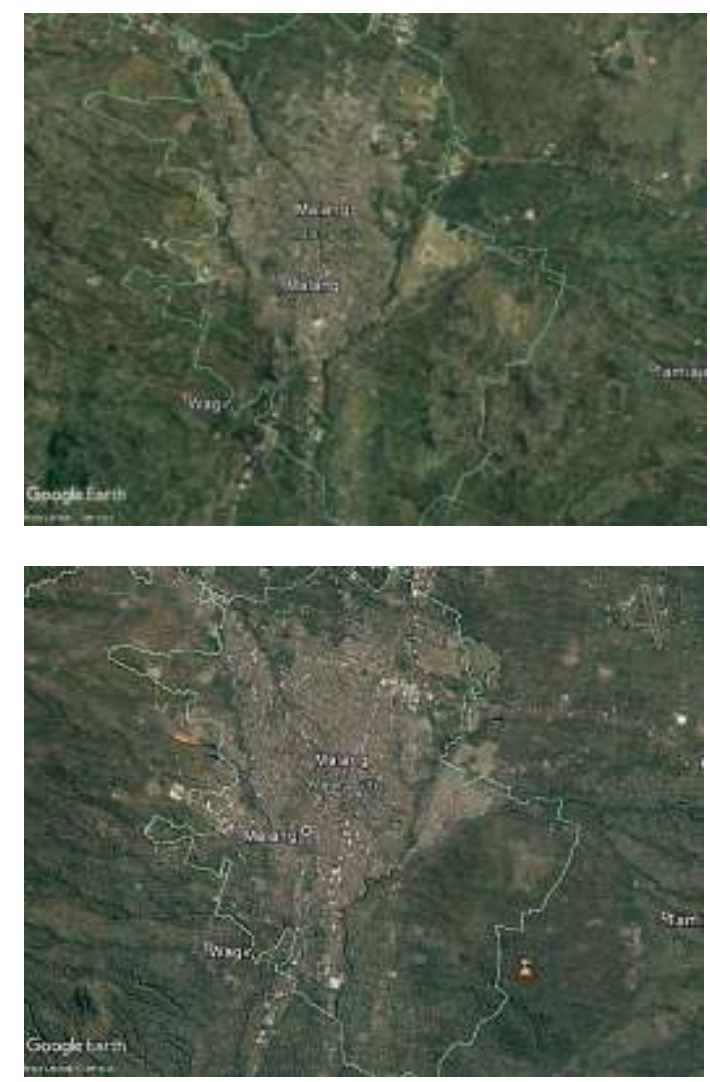

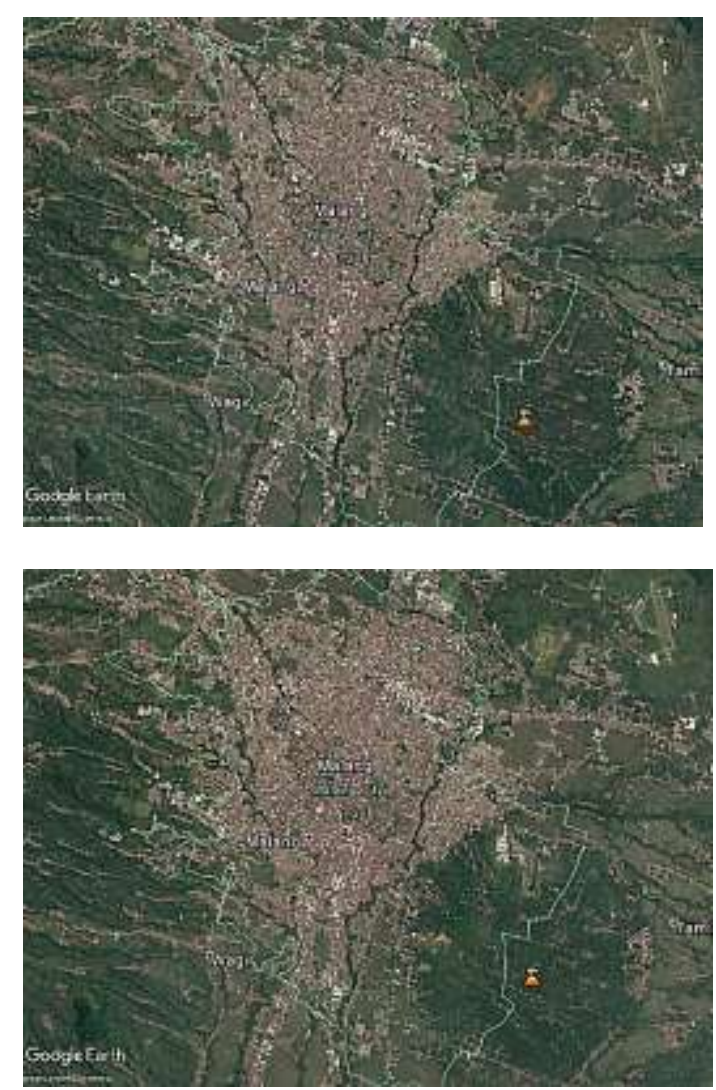

Gambar 4. Citra Google Earth Perubahan Penggunaan Lahan Kota Malang Tahun 1991—2016.

Berdasarkan gambar 4 menunjukkan perluasan perubahan lahan Kota Malang dari lahan terbuka menjadi lahan tertutup dari tahun ketahun semakin luas. Hal ini dikarenakan jumlah penduduk Kota Malang terus mengalami pertumbuhan dengan ratarata laju pertumbuhan penduduk tahun 1991-2016 adalah 0,76\%/tahun, namun luas wilayahnya tetap.

Meningkatnya kepadatan penduduk di Kota Malang berdampak pada peningkatan alih fungsi lahan, sehingga peningkatan suhu udara di Kota Malang juga ikut mengalami perubahan. Hasil analisis regresi antara tingkat kepadatan penduduk dan perubahan suhu udara di Kota Malang tahun 19912016 menunjukkan adanya pengaruh yang signifikan dengan nilai signifikansi 0,000. Kepadatan penduduk di Kota Malang memiliki pengaruh sebesar $49,6 \%$ terhadap perubahan suhu, sedangkan $50,4 \%$ peningkatan suhu dipengaruhi oleh variabel lain. Persamaan regresi antara pengaruh kepadatan penduduk dengan perubahan suhu adalah

$$
Y=19,838+0,001 X
$$

Persamaan regresi tersebut menunjukkan jika tidak terjadi kepadatan penduduk (X) maka nilai konsistensi perubahan suhu (Y) adalah sebesar 19,638. Setiap kenaikan $1 \%$ kepadatan penduduk (X) maka perubahan suhu udara (Y) akan meningkat 0,001 . Hasil regresi di atas didukung oleh teori Todaro (2000) yang menyatakan bahwa laju pertumbuhan penduduk memiliki pengaruh terhadap penurunan kualitas lingkungan. Dalam hal ini meningkatnya suhu udara dapat meningkatkan degradasi lingkungan. Sharifi (2015) mengungkapkan perubahan bentang alam menjadi bangunan perkotaan menyebabkan peningkatan ancaman terhadap perkembangan kota dimasa depan. Semakin banyaknya bangunan maka semakin tinggi pula panas yang terperangkap dalam bangunan, yang berdampak suhu udara wilayah kota terus meningkat dari waktu ke waktu.

\section{KESIMPULAN}

Berdasarkan uraian hasil penelitian di atas diperoleh kesimpulan bahwa kepadatan penduduk berpengaruh terhadap penggunaan tata guna lahan dan berpengaruh terhadap peningkatan suhu udara di Kota Malang dari tahun 1991-2016. 


\section{DAFTAR RUJUKAN}

BPS. 2013. Proyeksi Penduduk Indonesia 2010-2035. Jakarta: $B P S$.

IPCC. 2014. Impacts, adaptation and vulnerability. Contribution of Working Group II to the Fifth Assessment Report of the Intergovernmental Panel on Climate Change. Cambridge and New York: Cambridge University Press.

Kusrini, Suharyadi, Hardoyo S.R. Perubahan Penggunaan Lahan dan Faktor Yang Mempengaruhinya di Kecamatan Gunung Pati Kota Semarang. Majalah Geografi Indonesia, Vol 25, No.1. Maret 2011 (25-40).

Moonen, P., T. Defraeye, ., V. Doorer, B. Blocken, J. Carmeliet. Urban Physics: Effect of The Micro Climate On Comfort, Health, and Energy Demand. Frontiers of Architectural Research(2012) 1, 197-228.

Muta'ali, L. 2012. Daya Dukung Lingkungan Untuk Perencanaan Pengembangan Wilayah. Yogyakarta: BPFG Universitas Gadjah Mada.

Ritohardoyo, S. 2013. Penggunaan dan Tata Guna Lahan. Ombak: Yogyakarta.

Setiwawan, O. 20120. Analisis Variabilitas Curah Hujan dan Suhu di Bali. Jurnal Analisis Kebijakan Kehutanan Vol. 9 No. 1, April 2012 : 66-79.

Sharifi, E. dan S. Lehmann. 2015. Correlation Analysis of Surface Temperatur of Rooftops, Streetscapes, and Urban Heat Island Effect: Case Study of Central Sydney. Jurnal of Urban and Environmental Engineering Vol 9, No.1, 2015: 3-11.
Tjasyono, B. 2004. Klimatologi. Penerbit ITB: Bandung

Todaro, M.P. 2000. Pembangunan Ekonomi di Dunia Ketiga. Jakarta: Erlangga.

Utaya, S. 2008. Pengaruh Perubahan Penggunaan Lahan Terhadap Sifat Biofisik Tanah dan Kapasitas Infiltrasi Di Kota Malang. Forum Geografi, Vol.22 No 2 Desember 2008: 99-112. 